\title{
13 If Government Failed, how are we to Succeed? The Importance of History and Context in Present-day Irrigation Reform in Malawi
}

\author{
Anne Ferguson ${ }^{1}$ and Wapulumuka Mulwafu ${ }^{2}$ \\ ${ }^{1}$ Department of Anthropology, Michigan State University, East Lansing, Michigan, \\ USA; e-mail: fergus12@msu.edu; ${ }^{2}$ History Department, Chancellor College, University \\ of Malawi, Zomba, Malawi; e-mail:wmulwafu@chanco.unima.mw
}

\begin{abstract}
This chapter examines the interface between new, formal irrigation, water policies and laws and long-standing customary practices in two smallholder irrigation schemes earmarked for transfer to water user associations in Malawi. It documents how local histories and practices are shaping access to critical land and water resources in ways not anticipated by technocratic irrigation and water reform implementers. At this point, rather than creating a climate encouraging more equitable economic growth by making smallholder farmers' rights to land and water resources more secure, the opposite seems to be taking place as formalization opens the door for local elites to use diverse strategies to capture these resources.
\end{abstract}

Keywords: customary practices, irrigation management transfer, informal institutions, neo-liberal reforms, devolution, Malawi.

\section{Introduction}

Over the last decade Malawi, similar to other southern African countries, has revised most of its environmental and agricultural policies and laws. Since 1999 new irrigation, land, and water policies and supporting legislation have been approved by parliament. These new policies and laws aim to alter or formalize resource access and use practices, which once were under customary tenure, as well as to introduce new statutory laws and institutions. Customary land is to be titled under the rubric of 'customary estates', the use of water for productive purposes will require permits and fees, and government-run smallholder irrigation schemes are being turned over to users. These reforms will dramatically alter access to critical land and water resources for rural livelihoods in one of the poorest countries in the world.

This chapter focuses on the transfer of two government-run smallholder irrigation schemes in the southern region to farmers' associations in the context of the implementation of new irrigation, land and water policies, and pending laws. It provides a grounded analysis of the early effects of these reforms, drawing attention to how international and national policies and laws interact with existing informal and formal institutions and practices, and economic and 
political hierarchies, to yield sometimes unexpected results. Drawing on recent work by Benjaminsen and Lund (2002), Cleaver (2002), Mollinga and Bolding (2004) and others, the study examines problems inherent when blueprint reform models are implemented with little regard to context and history.

The following questions are addressed: how are reforms under way in the land, water and irrigation sectors likely to affect farmers in smallholder irrigation schemes? How do the new reforms interact with existing customary land- and water-related rights, privileges and practices? What are some of the outcomes of these interactions? Specifically, who may benefit from the transfer of the irrigation schemes to farmers' associations? Are these reforms likely to provide smallholder farmers - especially the disadvantaged - with equitable and secure rights to land and water resources as the policies espouse? Or will they create uncertainty and entrench privileged interests?

\section{Policy Context}

Malawi's economy is dependent on the export of primary agricultural products - particularly tobacco - for which the terms of trade declined significantly in the 1990s. More than $85 \%$ of the population live in rural areas, and per capita incomes have decreased significantly since the imposition of structural adjustment programmes in the 1980s. Approximately 45\% of the population presently live below the absolute poverty line of US\$40 per capita per annum, and $65 \%$ are considered poor by more conventional standards (Devereux, 2002a, p. 3). In the mid-1990s, Malawi had one of the poorest nutritional, health and poverty statistics of any non-conflicting country in the world, with no significant improvement in sight (Devereux, 2002a, p. 6). In 2002, the country experienced its worst famine in recent history (Devereux, 2002b). Without sufficient donor aid, 2006 may be an equally difficult year.

Deepening poverty and chronic food shortages suggest fundamental failures in development and poverty-alleviation strategies. Researchers point to the role of Washington Consensus neo-liberal economic policies and to government mismanagement and corruption in explaining this growing impoverishment (Devereux, 2002a; Owusu and Ng'ambi, 2002). Starting in the late 1980s, new government policies promoted by the World Bank and the International Monetary Fund redefined the role of the central government and restricted state intervention in the economy. Almost all policies in the natural resources and agriculture sectors have been rewritten, and new laws are being drafted and implemented reflecting these changes. Many call for turning over management of resources to user groups or local governments. The pace of reform is staggering. Since 1998, new irrigation, agriculture, land and water policies and, in many cases, laws have been drafted and approved by Parliament, in addition to a new local government Act (Ferguson and Mulwafu, 2004). This section briefly reviews these reforms, drawing attention to common elements in them to set the stage for an examination of their effects on the smallholder irrigation schemes.

As land pressure and climate change intensify, the government is turning to irrigated agriculture as a means to increase production. Expanded irrigation is expected to boost incomes and food security and is considered to be a way of reducing poverty. The National Irrigation Policy and Development Strategy (GOM, 2000) reflects this stance. It calls for the rapid phase-out of government support to the 16 smallholder irrigation schemes and their transfer to newly created farmers' associations. The policy also advocates the expansion and intensified use of informal irrigation by smallscale farmers along stream-banks and drainage lines and in wetlands, a form of irrigation that has received little government attention (Kambewa, 2004; Peters, 2004).

Transfer of government-run irrigation schemes to farmers' associations, often referred to as irrigation management transfer (IMT), has gained popularity in southern Africa as part of neo-liberal reform models. IMT is promoted as a means of decentralizing functions of the state, reducing public expenditure and mitigating the perceived dependency syndrome by instilling a sense of local ownership and responsibility. Four conditions are identified as necessary for successful IMT: (i) it must improve the life situations of a significant number of scheme members; (ii) the irrigation system must be central to creating this 
improvement; (iii) the cost of self-management must be an acceptably small proportion of improved income; and (iv) the proposed organizational design must be seen to have low transaction costs (Shah et al., 2002, p. 5; see also Vermillion, 1997; Vermillion and Sagardoy, 1999). The assumption is that these conditions require the introduction of new models of social organization and formal institution building, along with physical renovation of the irrigation schemes. Yet little attention has been paid to how past forms of social organization and existing customary practices may influence the creation of new institutions.

Malawi's land and water policies have also been revised. The new Land Policy (GOM, 2001) will essentially privatize customary land by creating 'customary estates'. Titling committees are to be established at the level of traditional authorities (TAs) and districts. Wetlands are to be designated as public lands under the control of TAs. Irrigation schemes are to remain public or government land, but will be leased to newly created water-user associations (WUAs). The Water Policy has been under revision since 1999 (GOM, 1999a, b). The draft 2000 Policy was approved by the Cabinet in 2002 but was subsequently rescinded, and a new Policy is about to be enacted in 2005 .

The new version (GOM, 2004) calls for the creation of catchment management authorities. It embraces demand management strategies, including user and polluter pay principles, and suggests that those using water for productive purposes will be expected to obtain water user or abstraction permits. No clearly stated right to water for domestic purposes is evident in the new Policy. Instead it states that: 'The protection and use of water resources for domestic water supply shall be accorded the highest priority over other uses' (GOM, 2004, 3.3.9). Water is to be treated not only as a social good but also as an economic good, with both entrepreneurs and individuals having 'equitable' access. Communities, non-governmental organizations (NGOs) and the private sector will bear the costs of infrastructural development, maintenance and operation (Ferguson and Mulwafu, 2001; Ferguson, 2005). The new Water Law, which will formalize and clarify many of the principles in the Policy, has not yet been approved.
These reforms governing critical natural resources must be considered within the context of the local government Policy and Law (GOM, $1998 \mathrm{a}$, b), which have initiated sweeping changes in how the government will operate. While line ministries will retain responsibility for policy formation, enforcement, standards and training, most administrative and political functions once concentrated in ministries at the national level are being transferred to districts and municipalities. The District Development Committee and Plan are the principal means by which integrated sectoral planning is to be achieved. Marking a significant change from the past, civil servants are now to be accountable to the populations they serve, not to their parent ministries in central government. The powers of TAs have been reaffirmed, and they are integrated into the new structure through their ex officio participation in District Assemblies, as well as serving as chairpersons of the Area Development Committees.

The new policies and laws differ significantly in the amount of public input and participation that took place during the drafting period. The new Land Policy was preceded by more than 6 years of study and broad-based consultation. In contrast, little public input into the Irrigation or Water Policies appears to have taken place. While the Land Policy was publicized on the radio, in the newspapers and through other means, information about the Water and Irrigation Policies has not been widely disseminated, and most Malawians appear to know little about them.

The new Irrigation, Water and Land Policies reflect the neo-liberal preoccupation with establishing the correct institutional framework to provide secure property rights, promote private sector investment, enact the user and polluter pay principles and decentralize and devolve ownership and management functions away from central government to local governments, communities and the private sector. Most policies and laws have been drafted at the behest of donor organizations and enacted on a sectorby-sector basis. Although they are being harmonized to resolve areas of ambiguity and conflicting clauses, questions about how the new structures will function in local contexts in relation to existing rights and practices have been largely overlooked. 


\section{Research Sites and Methods}

In Malawi, irrigated land includes formal irrigation schemes operated by the government and private estate owners, as well as lands along stream-banks, in low-lying areas of residual moisture and in wetlands cultivated by smallscale farmers. The formal irrigation schemes are often located in, and surrounded by, wetlands and depend on the same water sources. A recent World Bank estimate is that 28,000 ha are under 'formal' or 'semi-formal' irrigation, of which 6500 ha are under self-help smallholder schemes, 3200 ha under government-run smallholder irrigation schemes and 18,300 ha in estates (World Bank, 2004). The common estimate for the potential irrigated area (not limited to wetlands) is $250,000-500,000$ ha.

Our research focused on the Domasi and Likangala watersheds in the Lake Chilwa basin in the southern region (see Fig. 13.1). This basin is home to six of Malawi's 16 government-run smallholder irrigation schemes, all earmarked for transfer to farmers' associations. The two schemes forming the basis of our study are: Domasi irrigation scheme located on the Domasi river, Machinga district; and Likangala irrigation scheme on the Likangala river, Zomba district. Domasi covers approximately 500 ha and has 1500 farmers. The Likangala scheme is the largest in the Likangala complex, which comprises four smaller schemes as well Khanda, Njala, Chiliko and Tsegula. The study focused on the Likangala scheme itself, which is 450 ha in size and has nearly 1300 farmers. Each plot on these gravity-fed schemes is 0.25 acre in size. Rice is grown on the schemes during the rainy season. Rice, sweet potatoes, maize, pumpkins, watermelons, tomatoes and other vegetables are produced in the dry season. Some of the plots are reassigned for temporary use in the dry season by surrounding farmers who do not otherwise have access to the schemes.

The study took place between 2001 and 2004 and used quantitative and qualitative methods. In 2003, we conducted a survey of 123 farmers on the schemes to gather baseline information on access to plots, farming and marketing practices, water use and conflicts. We

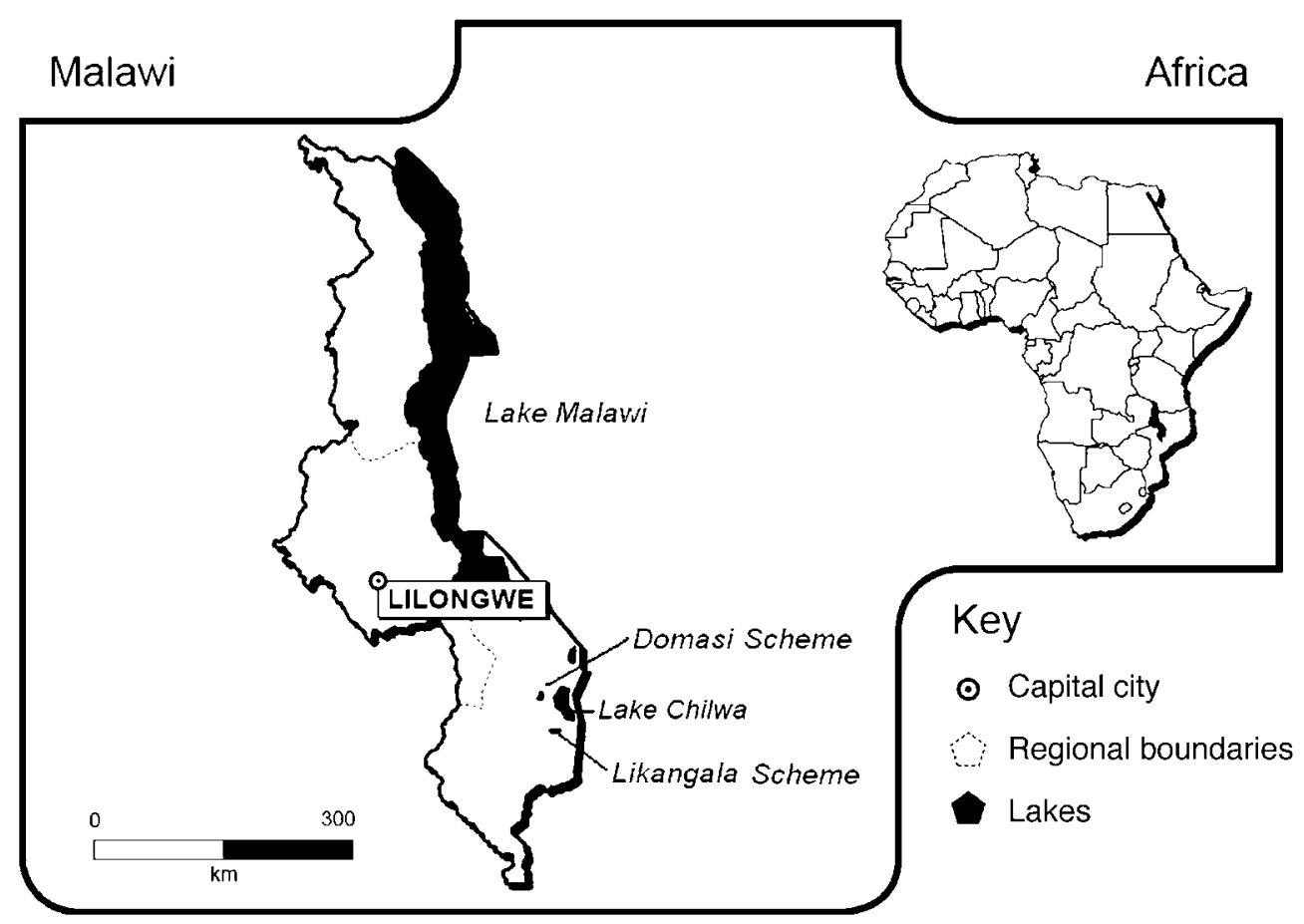

Fig. 13.1. Map of Malawi. 
interviewed 63 (51\%) farmers on Domasi and $60(49 \%)$ on Likangala. An irrigation transfer survey to gather information on scheme governance and farmers' knowledge of, and participation in, the transfer process was administered to 120 of those farmers, 61 (51\%) from Domasi and 59 (49\%) from Likangala. All those interviewed were plot-holders.

Two field assistants were assigned to live on the schemes for the 3-year period. In addition to engaging in participant observation and writing field notes, they carried out interviews with farmers and irrigation scheme committee members on assigned topics. The qualitative research enabled us to gather information on tenure and land-use practices, conflicts over land and water, scheme governance and farmer evaluation of the handover process, which was not accessible or reliable via formal survey research. To learn about developments in the policy arena, new policy documents and reports were collected, and key actors at the national and local levels were interviewed twice a year. These included interviews with officials in the Ministry of Water Development, the Department of Irrigation and the Ministry of Lands, along with major donors, including the International Fund for Agricultural Development (IFAD), US Agency for International Development (USAID) and the World Bank. At the local level, we interviewed irrigation scheme managers, committee members, officials of the Agricultural Development Division, district authorities and project managers of the Balaka Concern Universal office responsible for training farmers on the Domasi scheme to form a WUA. Finally, we presented preliminary research findings for discussion to policy makers, project implementers and farmers through a series of workshops conducted over the research period.

\section{History and Present Context of the Domasi and Likangala Irrigation Schemes}

\section{Historical background}

Malawi's 16 government-run smallholder irrigation schemes were established in the late 1960s and early 1970s to demonstrate the methods and benefits of intensive cash crop production. The Land Act of 1965 provided for the creation of settlement schemes to foster increased peasant production (GOM, 1965). These schemes came to be closely identified with the Malawi Young Pioneers (MYP), a paramilitary wing of the ruling Malawi Congress Party (MCP) (Nkhoma and Mulwafu, 2004). Established in 1965, the MYP was originally a movement meant to integrate the youth into agricultural development. Training bases, which in some cases served as settlement schemes, were established where primary school graduates received 10 months of basic training in leadership, civics, agriculture and community development. As time went by, the MYP became involved in political matters as on-the-ground watchdogs for the country's authoritarian leadership. They were infamous for maintaining discipline and ensuring compliance with party dictates, such as the purchase of party cards.

To establish the Domasi and Likangala irrigation schemes, customary land was appropriated from TAs. State authorities consulted with chiefs, since the latter's cooperation was critical in getting the schemes off the ground. In one case, the Group Village Headman, Namasalima of the Zomba district, refused to grant land for the establishment of the scheme, citing among other factors loss of land for his subjects. The state then went to Group Village Headman Mpheta in the neighbouring Machinga district, who welcomed the idea, and the location of the scheme was changed. Villagers displaced by the schemes were resettled in surrounding villages and given plots, often in the same irrigation blocks. A small number of settlers, plus the MYP, came from outside the Lake Chilwa basin, but the majority of plot-holders were, and continue to be, from nearby villages and towns. We found that most of the farmers interviewed were born in the district where the scheme was located $-83 \%$ of respondents in the case of Likangala and $84 \%$ in the case of Domasi while the remainder came from nearby districts.

Between the late 1960s and the 1980s, the schemes were fairly well maintained but run in a top-down, authoritarian fashion by the government (Krogh and Mkandawire, 1990). Management was formalized with the promulgation of specific rules and regulations on irrigation farming. This was followed by the creation 
of two departments to oversee irrigation matters in the country, the Departments of Irrigation and Settlement (GOM, 1965, 1968). As was the case with irrigation schemes elsewhere in eastern and southern Africa, farmers were supposed to comply with statutory regulations on plot allocation, use and maintenance of canals, water allocation and use, and cropping calendars (Adams et al., 1997; Bolding et al., 2004).

Initially, the Taiwanese (Chinese) Agricultural Technical Mission provided support on the technical and managerial aspects of irrigation farming. Local chiefs assisted the Taiwanese in handling sociocultural matters, such as resettling villagers, conflict resolution and plot allocation. In the early 1970s, however, Land Allocation Committees were established to manage the schemes. Members were political appointees who often had to receive the support of MCP authorities in order to retain their positions. In fact, these committees were invariably chaired by MCP officials and chiefs, and MYP Discipline Officers were ex officio members. The Land Allocation Committees implemented statutory laws and regulations with a considerable degree of coercion (Chilivumbo, 1978). The system was highly regimented, and farmers were required to follow rules to the letter. Failure to comply often resulted in severe punishments, such as uprooting of crops or eviction. In part, this authoritarian structure explains why the performance of the schemes has been described as efficient up to the beginning of the 1990s.

That success, however, should be understood within the context of the embeddedness of the management regime in the wider national authoritarian political processes. There was an intricate fusion between statutory and socially embedded institutions on the irrigation schemes. Although the schemes were on public land, where formal rules had to be applied, informal arrangements with powerful political actors developed, and these were instrumental in the management of the schemes. While the Departments of Irrigation and Settlement represented the formal management structure, they were often overridden by chiefs, MCP officials and MYPs who acted out of the existing and workable local conditions.

The deepening economic and political crises of the 1980s, coupled with the withdrawal of Taiwanese support, forced the government to reduce its role in scheme management and upkeep. During the 1990s, in particular, physical infrastructure deteriorated. As Malawi made the transition from authoritarian rule under President Banda to a multi-party democracy in the mid-1990s, farmers often ignored cropping calendars and other rules established during the Banda regime. In 1993, the MYP was disbanded and most settlers brought in by the movement were evicted from the schemes. Although the reasons for these actions had little to do with agriculture, farmers believed that this signalled their emancipation from the previous regimental scheme management. Thus, since the early 1990s, many of the formal authority structures governing the smallholder irrigation schemes have lost legitimacy and are frequently ignored. Farmers felt that the old rules and regulations were unfair and, like the regime that imposed them, should be rejected.

Following the dissolution of the MYP, a power vacuum crept into management. The government established Scheme Management Committees (SMCs), consisting of elected members from the plot-holders as the new scheme-governing structure. The Irrigation Officer, a government employee in charge of the scheme, served as an ex officio member of the committee, but in practice retained most of the authority. The sweeping political and economic reforms in the last 10 years have reduced the number of civil service and agricultural extension posts and slashed public sector budgets. As noted, farmers themselves have resisted imposition of SMC authority. Consequently, the new structure has been highly ineffective, often laden by problems of corruption, poor governance and lack of direction, as described more fully below.

\section{Present context}

How is this legacy reflected in current efforts to transfer management of the smallholder irrigation schemes to farmers? It is against this background that the government, with pressure from donors, has opted to hand over the schemes to farmers' associations. With IMT gaining international acclaim, Malawi began the process 
that, to date, has resulted in more complications than solutions. From the mid- to late 1990s, experiments with IMT yielded inconclusive results. The Food and Agricultural Organization (FAO) and Danish International Development Agency (DANIDA) both funded a study of three pilot schemes, which were to be rehabilitated and handed over to farmers. DANIDA never completed its work due to political disagreements over issues of corruption with the Malawi government, which led to the suspension of aid and the closure of Denmark's embassy in 2001. When FAO completed its technical report no follow-up was made until 1999, when IFAD launched the Smallholder Flood Plains Development Programme. This project targeted physical rehabilitation, training and transfer of responsibilities to farmers' associations. However, the programme was driven by an engineering mentality with little appreciation of the complexities of the history and the social relations that had characterized the schemes during and after the departure of the MYP.

About the same time, a few social scienceoriented studies revealed some deeply ingrained problems in the schemes. Kishindo (1996), Cammack and Chirwa (1997) and Chirwa (2002) showed that poor conditions existed and that human rights had, in some cases, been infringed. Their studies revealed low earnings, high rates of farmer turnover, lack of farmer participation, land dispossession, gender discrimination and autocratic administration by scheme management authorities. These findings suggested that irrigation farming was far from achieving the proclaimed goal of increasing agricultural productivity and attaining national food security. All this resonated well with the discourse on the need for IMT and provided fuel to draft and implement the new irrigation reform.

At the time of this study, the Likangala and Domasi irrigation schemes differed in the condition of their physical infrastructure, degree of farmer mobilization and source of funding for renovation and transfer of the schemes to farmers. Since its inception in 1972, Domasi has been fairly well supported by government and donor organizations, particularly the Taiwanese Agricultural Technical Mission and, most recently, IFAD. Although still in need of renova- tion, its physical infrastructure is in better condition than that of Likangala. Domasi also is further advanced in the process of forming a WUA, adopting a constitution and by-laws and is likely to be the first smallholder irrigation scheme in Malawi to be formally handed over to the farmers' association. Likangala, in contrast, has received less government and donor support since it was established in 1969. Renovation and training have proceeded slowly, and it was not until August 2004 that preparations for establishing a farmers' association were initiated and a new constitution was adopted. Likangala was originally scheduled to be renovated with Highly Indebted Poor Country funds but, as of 2006, it appeared likely that the World Bank would become the new donor.

Our research revealed that the smallholder irrigation schemes play a vital role in both the local economy of the Lake Chilwa basin and the well-being of the farmers on them. Farmers on both schemes had diverse livelihood strategies. In addition to their irrigation plots, $93 \%$ reported having upland rain-fed fields, and $45 \%$ had either wetland or stream-bank gardens. Further, many plot-holders had sources of income in addition to farming: $40 \%$ listed casual labour, 19\% marketing of crops, $23 \%$ owned small businesses and $9 \%$ had other occupations. Despite their engagement in other occupations, farmers reported that the irrigation plots constituted the major source of their household food supply and cash earnings.

The two irrigation schemes differed in important ways. There were differences in the number of years farmers had held plots, with turnover on Likangala being higher than that at Domasi. Domasi had a higher percentage of farmers (44\%) who had been on the scheme for 20 years or longer as compared with Likangala $(17 \%)$. When the irrigation scheme lands were originally parcelled out to farmers in the late 1960s and early 1970s, they received two to four plots, each one constituting 0.25 acre. The baseline survey revealed that the average number of plots held was greater on Domasi than on Likangala. The Domasi mean was 3.9, while on Likangala it was 2.7. Overall, $18 \%$ of the total sample reported farming five plots or more $-8 \%$ of Likangala farmers and $17 \%$ of Domasi farmers. 
In order to estimate differences in wealth among farmers, a ranking of the households' assets was undertaken, with scores ranging from 7 to 1576 . Households were clustered into three wealth categories. Over two-thirds fell within the lowest part of the range, $26 \%$ in the middle and $7 \%$ in the top asset group. This distribution reflects the overall distribution of poverty in Malawi and in the southern region in particular. A slightly higher percentage of Domasi than Likangala farmers had asset scores in the middle and upper clusters.

Overall, our findings indicate that the irrigation scheme constituted farmers' major source of livelihood - including food for household consumption and cash earnings. However, the differences presented above suggest that Domasi plot-holders were somewhat wealthier than those on Likangala. Irrigation scheme farmers are, on average, better off than Malawians who do not have access to dry-season irrigated fields. Many scheme farmers are able to plant twice a year or more and, consequently, are not as likely to experience food deficits as those without access to dry-season gardens. While they are not among Malawi's poorest farmers, many plotholders remain vulnerable, as the asset profile reveals. During the January-March 2002 period, the height of the famine, the field assistants reported that some people on the schemes were consuming maize husks and grasses. Deaths, aggravated if not entirely caused by hunger, also occurred.

\section{The Implementation of New Policies and Laws}

The institutionalization of the new Irrigation, Land and Water Policies and Laws on the Domasi and Likangala irrigation schemes has just begun. In this section, we explore how this process is being shaped by local histories as well as by existing informal institutions, practices and power relations. Irrigation reform policy makers and programme implementers, for the most part, are unaware of these complexities and are often surprised when they yield unanticipated results. For example, in discussions on the status of Likangala and Domasi schemes, a member of a recent irrigation renovation project development team remarked that the donor organization would seek to avoid including schemes where there were social conflicts, unaware that this was the norm, not the exception, in most schemes.

Processes of formalization and informalization of irrigation, land and water rights produce complex situations "which are neither regulated by predictable rules and structures nor characterized by sheer anarchy' (Benjaminsen and Lund, 2002, p. 3). While the terms formalization and informalization are often used in policy and academic literature, as Cleaver (2002) points out, they polarize reality. Her concept of institutional bricolage represents a means of framing the complex interactions among state-sponsored statutory and bureaucratic reforms and existing local institutions, practices and power relations. This approach allows us to analyse the dynamic arrangements that develop when new institutions and social relationships are adapted to existing conditions and power relations.

In this section, we demonstrate how the transfer of authority to user groups, as advocated in the Irrigation, Land and Water Policies, provides the opportunity for these groups to institutionalize not only newly established laws and procedures but also practices that were previously regarded as customary or informal in nature. This context opens the door for the powerful and well-positioned to capture resources and authority, and for others potentially to challenge them. Benjaminsen and Lund (2002, p. 1), for example, point to the importance of such everyday politics of institutionalization of rights and exclusion, noting that: ' $\ldots$ it becomes all the more important to investigate empirically how local-level competition, conflict and power reshape social institutions and move with a distinct dynamic that does not necessarily fit with dominant discourses.' The following discussion on the implementation of the Irrigation, Water and Land Policies parallels experiences found in other countries in the eastern and southern African region (Bolding et al., 2004; Juma and Maganga, 2005).

\section{Traditional authorities and new structures of irrigation scheme governance}

The rapid pace of reform has raised a number of controversial issues in the management of 
the smallholder irrigation schemes. One such issue concerns the role of TAs. Under the previous Land Policy and Law, the smallholder irrigation schemes were classified as public land, and they are earmarked to remain so in the new Land Policy and Law. The newly formed WUAs are to lease the schemes from the government. The new Domasi and Likangala constitutions state that chiefs are not to take part in plot allocation or dispute resolution on the schemes, although in the past they, at times, had played an unofficial but important role in these processes. The new Local Government Act and Decentralization Policy give chiefs identified roles in local administration, as Heads of Area Development Committees and ex officio members of District Assemblies, as discussed above (GOM, 1998b). In this section, we discuss some of the understandings that irrigation farmers have concerning the role of chiefs, which underscore the importance of past histories and traditions and which may result in future conflicts.

To begin with, farmers have different understandings of the tenure status of the schemes under the new legislation. Our study indicated that many were unaware that the WUAs were to receive leases from the government: $37 \%$ thought the scheme would revert to customary land; $27 \%$ thought it would become their own private property; $13 \%$ thought the WUA would be the new owner; only $16 \%$ were aware that the scheme would remain government land. This has given rise to uncertainty over the roles of chiefs in solving disputes that develop, especially between farmers on and off the schemes. When asked who solves such disputes, $57 \%$ said they were solved by the WUA Executive Committee or the Scheme Management Committee and $38 \%$ said they were solved by chiefs, while 5\% said they didn't know. Because decentralization and many other processes of reform are occurring simultaneously, lines of authority are often unclear to farmers, and sometimes even to officials. This raises opportunities for multiple interpretations of rights and competing claims to land, water and other resources.

These differing interpretations regarding the tenure status of the schemes and the plots on them have given rise to conflicts. At Likangala, the widely held perception that the land will revert to farmer or customary control has opened the door to attempts by village headmen to reclaim ancestral lands. There, one village headman encouraged farmers from his village to take over plots on Blocks $\mathrm{B}$ and $\mathrm{C}$ from other farmers. His claim to these blocks was based on his assertion that these were his ancestral lands and, since the scheme was being turned back to farmers, the plots should be allocated to those from his village. He drew on past history to make these claims. This headman and many members of his village were exiled to Mozambique when former President Banda banned the Jehovah's Witnesses in the early 1970s. When they returned to the area in the early 1990s, they had very little land on which to cultivate and were refused access to all their original scheme plots (Nkhoma and Mulwafu, 2004). Other village heads have threatened that, if this headman is allowed to claim the scheme land as his village land, they will do the same.

The farmers who had been displaced in Blocks $\mathrm{B}$ and $\mathrm{C}$ reported the case to the Scheme Management Committee for resolution. When the matter had been discussed for more than a year and no binding decision was reached, it was taken to the TA as a socially recognized authority. Unfortunately, the TA also failed to resolve the matter and, at this point, referred it to the District Commissioner. Upon hearing views from both parties, he called for a meeting of all farmers in the scheme to announce his verdict. However, in a surprising turn of events, he asked the TA to pronounce the verdict, which was that those who had invaded plots should give them back to the farmers they took them from at the end of the harvest season. This particular example illustrates some of the ambiguities that exist in making claims to plots and in resolving disputes. The local government and irrigation reform processes have allowed old claims based on persisting local custom to be revisited, and have involved both customary and statutory authorities in dispute resolution.

\section{The new irrigation policy in the local context}

Drawing on previous experiences and present social location, farmers were divided in their 
support for the transfer of the schemes to farmers' associations. On both irrigation schemes there was significant opposition. Some plotholders, particularly the wealthier ones, feared that the transfer to farmer management would potentially remove their opportunities for accumulation, as new rules concerning access and plot allocation could be put in place. Others were concerned that transfer would open the way for more 'outsiders' to gain access to plots. Still others, in line with the past history of irrigation reform, regarded rehabilitation as a government responsibility and were reluctant to take over the schemes until they had been completely refurbished. Indeed, in 2003, farmers at Likangala opposed the transfer because they were afraid they would inherit a dilapidated main canal and other structures they could not afford to fix. Many stated that they did not see how they could succeed in repairing and running the scheme when the government, with all its resources, had failed in doing so.

As mandated by the new Irrigation Policy, WUAs are being established on the Likangala and Domasi irrigation schemes, but through different means and with quite different results, reflecting local histories and interactions between formal and informal institutions and practices. At Domasi, the rehabilitation and handover process was instituted with funding from IFAD in 2000. Although the model employed called for farmers to participate in setting the conditions of the transfer process itself and for them to receive training in scheme maintenance and management, it did not occur until very late in the renovation process. Concern Universal, an NGO, was contracted in 2002 to provide farmer training at a point when most decisions regarding physical rehabilitation had already been made and renovation was well advanced. At Likangala, farmers were mobilized to supply labour for rehabilitation, but little farmer capacity building had occurred. The priority given to physical renovation reflects the backgrounds of the majority of civil servants in the Irrigation Department. Most are engineers who see renovation as a technical problem requiring little social input.

Actual rehabilitation of canals, headworks, roads and other facilities on both schemes has proceeded slowly due to numerous factors. These included delays in the arrival of funds and supplies, problems with local contractors and heavy rains that destroyed renovated structures. Other factors with social and historical origins have caused delays as well, including inputs disappearing or being stolen and farmers' reluctance to provide labour. These delays have been great at Likangala, which has depended on government funding for renovations. At Domasi, delays have resulted in two postponements of the targeted date for scheme handover to the WUA. Initially, transfer was scheduled for 30 December 2002, and then for 30 September 2003. By mid-2004, government officials recognized that rehabilitation and handover would not be a single event completed by a specified date and marked by a celebration and photo opportunities for politicians, planners and donors. Rather, it was likely to be a phased process taking much more time and getting more complicated than originally anticipated.

At Domasi, almost all farmer capacity building has focused on preparing the newly elected WUA Executive Committee members to carry out their functions, rather than on the general WUA membership. Indeed, only 15 (13\%) of the farmers in the overall sample said they had received some training on handover issues. Twelve of these were from Domasi, and all of them were members of various scheme committees. Under the 'Training of Trainers' model used by Concern Universal, the assumption was that these farmers would inform and train their neighbours, a process that did not take place. Farmers who had undergone training expected support and payment to train others and, failing this, many did little to pass on information.

Indeed, WUAs have played no real role in decision making. Most decisions concerning the Domasi scheme were made by a small group of newly elected WUA Executive Committee members and government scheme officials and were announced at general WUA meetings. Indeed, reflecting the authoritarian base of past 'elected' Scheme Management Committees, although technically elected by WUA members, most of those on the new Executive Committee were members of the previous Scheme Management Committee, composed primarily of a small group of wealthier plot-holders, their relatives and friends. Not surprisingly, such 
concentration of knowledge and authority in the hands of a small number of committee members mirrors the previous top-down administrative practices. It also suggests that most farmers on the schemes are poorly equipped to exercise their rights and obligations in the new governance structures. In fact, the handover survey revealed that the majority of Domasi farmers did not understand that the WUA was their membership organization: most thought it was a new name for the Scheme Management Committee.

At Domasi, a small group of relatively welloff farmers has maintained control of the WUA Executive Committee and other newly established committees. Some of these farmers owned more than ten plots each, often those with the best access to water. Actual plot ownership at the household level was greater than these figures suggest, as spouses and children had plots registered in their names as well. These farmers received extensive capacity building from Concern Universal, including the opportunity to travel and observe other WUAs being established on irrigation schemes in other parts of the country, as well as a trip to Italy for the Executive Committee President to receive training in marketing and general management of smallholder irrigation schemes. This training has helped consolidate and legitimize their present positions and their views of the future of the scheme.

At Likangala the WUA was being organized, its constitution enacted and a new SMC elected at breakneck speed in July and early August 2004. This was instigated by Zomba Rural Development Project (RDP) officials under the assumption that a WUA had to be in place to allow the scheme to qualify for newly available World Bank renovation funding. A "participatory and consultative' meeting on problem identification and constitution building occurred at Likangala in early July 2004, involving village headmen and other TAs, scheme committee members, RDP officials and only a small number of ordinary plot-holders. One week later, RDP officials presented the constitution for ratification at a general farmers' meeting attended by fewer than 20 farmers who did not hold elected or appointed office. Few farmers knew that there was a draft constitution or that a meeting was going to take place to discuss it, let alone the provisions contained in the document itself. At the ratification meeting the constitution was read to the farmers, who were asked to endorse it. Barely 1 week later, another meeting was held to elect a new SMC. This committee, like its predecessor, was composed of relatively wealthy and influential farmers. This top-down process echoed the way schemes were run during the Banda era and may well be challenged by Likangala WUA members in the future, if they are sufficiently organized.

In essence, the transfer of authority for scheme management to WUAs, as required by the Irrigation Policy and Law, opened the door at Likangala for the state to reassert its authority via an alliance between the RDP and newly elected SMC, while at Domasi it resulted in the further consolidation of the power of local elites in control of the WUA Executive Committee. These differences are reflected in the provisions in the two new constitutions. While they show some similarities, these constitutions also reflect differences rooted in the histories, contemporary practices and power relations existing on the two schemes, giving rise, at this point at least, to different visions of the schemes' futures.

At Likangala, the state, in the guise of the newly elected SMC, has sought to reinstate many of the rules and regulations that characterized the irrigation schemes in the 1980s. In contrast, at Domasi, the Executive Committee has adopted new provisions that formalize many informal practices that developed particularly during the 1990s, allowing greater concentration of land and other resources. We examine below how some of the key provisions of the new constitutions reflect history and context just as much as they do the new procedures and rules set out in the Irrigation Policy.

\section{Rules limiting access}

One contentious debate that took place in constitution drafting related to who should have rights of access to plots. Should it be people from surrounding villages, any person from Zomba or Machinga districts or any citizen of Malawi? When the schemes were established, as noted above, the land was converted from the customary to the public tenurial system. 
Until the adoption of the new constitutions, any citizen of Malawi could technically ask for a plot by applying to the SMCs. In the immediate post-Banda period, absentee farmers and plotseekers from urban areas increasingly began to obtain plots through informal renting and borrowing/lending arrangements and, in some cases, preferential allocation from the SMCs.

Many farmers and village headmen opposed this influx; they considered the land their ancestral territory to be inherited by their children and grandchildren. Reflecting these issues, both constitutions contain clauses limiting scheme access to residents of the area. The Likangala constitution states that access to plots is dependent on being from Traditional Authority Mwambo. The Domasi constitution contains a similar, if somewhat more vague, clause asserting that access is limited to citizens of Malawi who are residents of the area. This focus on local ownership reflects the historical tensions concerning displacement from ancestral lands, as well as more recent concerns that plots are being unjustly allocated to outsiders.

\section{Rules concerning WUA membership criteria, plot ownership and inheritance}

The two constitutions reflect quite different WUA membership criteria - clauses that are closely related to the new regulations concerning plot ownership and inheritance. At Likangala, the unit of membership was identified as the banja (family), consisting of husband, wife and children, while at Domasi it was identified as the individual. These variations are reflected in different provisions concerning the number of plots that can be owned. When the irrigation scheme lands were originally parcelled out to farmers, they received two to four plots, the area of each being 0.25 acre. Original by-laws on both schemes prohibited ownership of more than four plots and also forbade the practices of renting or lending plots. Many farmers believed that these rules were still in place and made efforts to disguise practices of renting, lending and plot accumulation in various ways.

The new constitutions have adopted quite different policies concerning these practices. The Likangala constitution states that families may own no more than four plots in total. It is too early to determine whether the SMC, some of whose members have considerably more than four plots, will be willing to enforce these limits. It is worth noting, however, that the very people who have been given authority to enforce the new regulations are the ones known in the past for violating them. At Domasi, on the other hand, the constitution does not specify the number of plots an individual can have, stating rather vaguely that WUA members have a right to 'a profitable landholding size according to agreed criteria for land allocation'.

In a similar fashion, the Likangala constitution seeks to reinstate or reinforce older prohibitions on renting of plots, stating that farmers found to be renting out plots can be fined and ultimately removed from the scheme. The older regulation, that land not cultivated for 2 years reverts to the SMC, had spurred renting as a means of dealing with hardships of various kinds. Those who were unable to cultivate because they lacked inputs, did not have sufficient labour or were sick, often rented or lent their plots to better-off farmers and ended up working as labourers on their own or others' fields. At Likangala, despite its illegal status, it may be difficult to halt renting for at least two reasons - its widespread occurrence and the fact that it meets the needs of both wealthy and poor farmers. The Domasi constitution, on the other hand, is mute on the issue of renting, presumably permitting it to continue and thus formalizing what had become a common informal practice during the 1990s.

As tight control over the schemes collapsed, farmers became accustomed to leaving their plots to their spouses, children and other relatives. The new Domasi constitution states that plots can be left to a specified next of kin, who must be identified on the plot-holder's WUA membership card. The Executive Committee has the power to approve or reject this choice, as it has the authority to determine whether the next of kin meets membership criteria. The goal is to limit inheritance to one family member in good standing with the WUA. This clause may well generate opposition in the future as more farmers become aware of it, since it contradicts what has become local inheritance practice. In the opinion of many Likangala farmers, it is only when the plot-holder is unmarried and has no offspring that the plots revert to the SMC for 
redistribution, and then usually half goes to relatives of the deceased and the remainder to non-family members. However, the new Likangala constitution states that, upon the death of the holder, the plots are to revert to the $\mathrm{SMC}$, which may redistribute them to the relatives of the deceased or to others as they see fit. In the past, the SMC had sometimes used the occasion of the death of a member to obtain plots and reallocate them, often to powerful, influential people, including members of the committee itself. Given these practices, this inheritance clause in the Likangala constitution may also generate opposition once it becomes more widely known.

Malawi's new land reform may have impacts on women's rights to irrigated land. Women's access to plots and voice in management have not been addressed directly in farmer training on the irrigation schemes to date, although the new Irrigation Policy includes normative statements supporting women's equal participation in irrigated agriculture. The Domasi and Likangala schemes are located in an area of matrilineal inheritance. Reflecting the patrilineal biases of most development planners at the time when the schemes were established, plots were registered in the names of men as heads of families. Over the years, however, many women have gained access to plots using various strategies, including appeals to cultural traditions that recognize matrilineal inheritance of land and other property. In 2003, Concern Universal estimated that, of the 1500 registered plot-holders at Domasi, $47 \%$ were women. Asked whether women should be allowed to register plots in their own names, an overwhelming $95 \%$ of the Domasi respondents said that they should, while $88 \%$ affirmed the same at Likangala. At Likangala, where the 2004 constitution limits the number of plots a family can hold to four, it is not clear what will happen to plots registered in a woman's name when the husband also has plots and the total number exceeds four.

The new Land Policy and Law propose to make inheritance more equitable by not recognizing either customary patrilineal or matrilineal inheritance practices, calling instead for children of both sexes to inherit equally from parents. It is too early to determine what the effects will be on women's land rights but, in a context where patrilineal inheritance continues to be taken as the norm by most donors, policy makers and decision makers, women in the Lake Chilwa basin and other matrilineal areas in the south and centre may lose rights to valuable irrigated land, while those in patrilineal areas may not gain more rights.

\section{Rules on dry-season rotation of plots}

Older by-laws on both irrigation schemes contained clauses requiring dry-season rotation of plots. The SMCs would reallocate plots each dry season, allowing those who did not normally have access to these valuable lands to use them temporarily. Farmers interviewed were generally supportive of this practice: $83 \%$ said it should be continued after handover for a number of reasons, including that it helped people who did not have enough food and gave access to those who did not have plots or whose lands did not receive enough water. Although farmers were supportive of this dryseason plot rotation, many criticized the way it was carried out, claiming that the SMC was corrupt and often allocated plots, not to the poor, but to better-off farmers and city dwellers. The new Domasi constitution does not mention dry-season rotation, presumably because it interferes with securing property rights and is not in the interests of those now in control of the new WUA Executive Committee. At Likangala, on the other hand, the new SMC is set to continue this practice.

\section{Irrigation reform in the context of water reform}

This section looks at the interface of the water and irrigation reforms. It shows the challenges of implementing provisions of these reforms against the backdrop of local histories and the broader political, social and economic context. Particular attention is paid to the implications of these reforms for class and gender disparities on the irrigation schemes.

Although the Water and Irrigation Policies and Laws are being harmonized to resolve areas of ambiguity and conflicting clauses, questions about how the new structures will function in local contexts in relation to existing rights, prac- 
tices and resources have been largely ignored. One of these questions involves the creation of Catchment Management Authorities (CMAs), as proposed in the new Water Policy and pending Law. The policy calls for Malawi to be divided into catchment areas, which are drawn according to hydrological criteria and, in many cases, cross political-administrative boundaries. Two or more districts or TAs may fall within one CMA. While the catchment approach may make environmental sense, it creates another administrative structure that has to be negotiated and financially supported. It is unclear how CMAs will work with District Councils and other political administrative units.

In fact, this has been a significant issue in Zimbabwe, where the same organizational structure was put into place (Derman et al., 2000). There, CMAs include representatives of districts, local representatives of various ministries, and major water users such as commercial farmers, smallholders, and mining and urban water user representatives. For district authorities and smallholder farmers alike, the transaction costs of participating in meetings are high, and they often lack funds to attend. Water users also have to travel long distances to CMA offices to pay fees or obtain services (Derman et al., 2000; Nicol and Mtisi, 2003). In Malawi, more serious financial problems exist as well, as sustainable sources of funding for the CMAs have yet to be identified.

WUAs are likely to be represented in the proposed CMAs and expected to participate in meetings using their own resources, which will require that they raise funds from fees collected from water users, the majority of whom are poor. This may be a major limiting factor for the effective participation of WUAs in the new structure for management of water resources.

Malawi's 2000 Water Policy and 1999 Draft Law have recognized people's right to water for 'primary' purposes, defined as the provision of water for household and sanitary purposes and for the watering and dipping of stock (GOM, $1999 \mathrm{~b}$, part 1.1). As noted above, the 2004 Policy no longer uses this rights-based language. Instead, it states only that the protection and use of water resources for domestic water supply are to be given the highest priority over other uses. Presumably the new law, once drafted and approved, will provide clarification.
Users of water for productive purposes are likely to be required to obtain a water use permit. Current suggested guidelines in this regard indicate that an applicant will need to provide information on particulars of the land, e.g. freehold or leasehold, name or description and type of body of water from which the water is required, the point of abstraction, the amount required and the purpose of use. The payment would be made on an annual basis, with the permit renewable every 5 years. Water rentals would be determined by the amount of water to be abstracted. Again, we must await the drafting and enactment of the Water Law for clarification.

Small-scale irrigation is considered a productive use of water, and WUAs will have to obtain a water use permit, with the payment of fees passed on to plot-holders. Many scheme farmers also have other small parcels of land they farm and may have to obtain a water-use permit on their own as well. Collection of these fees promises to be an arduous task for the government, considering the high levels of poverty plus the considerable transaction costs involved in collecting fees from large numbers of smallholders unaccustomed, and often unwilling, to pay for water.

The experience from Tanzania perhaps best illustrates the seriousness of this problem. State attempts to introduce water permits and water pricing among small-scale users in the riverbasin organizations in the mid-1990s ended in failure. Not only was the process of registering water users laborious and time-consuming, but the transaction costs were extremely high. Moreover, even when the users had organized themselves into WUAs, the risks of corruption and marginalization of the poor were significant. In these cases WUAs run the risk of becoming one more means through which wealthier water users advance their own interests at the expense of the poor (van Koppen et al., 2004). In both Domasi and Likangala schemes, it is the wealthy and elite farmers on the WUA management committees who have so far benefited from new opportunities provided by the irrigation reform in terms of training, access to information and abilities to shape the rules governing scheme functioning.

One option for Malawi to consider is to legally recognize a smallholder's right to water 
for both productive and domestic purposes. This right would not require individual or collective titling or permits. It would: (i) take into account the importance that water plays in livelihood strategies; (ii) recognize that the majority of small-scale farmers lack the means to pay user fees or could best use the money for other productive purposes; (iii) acknowledge that many smallholders do not believe that water should be commoditized, and grant them a voice in deliberations over water use without having to register; and (iv) avoid having to collect fees from all of them or their organizations - a nearly impossible task in any case. Registration and collection of water permits and user fees, for the immediate future at least, can best be concentrated on large-volume water users (Electricity Supply Commission of Malawi (ESCOM), Water Boards, private estates, etc.).

\section{Concluding Remarks}

Malawi has embarked on what constitutes a radical redefinition of tenure and governance structures related to key irrigation, land and water resources. These new policies and laws draw from neo-liberal development thinking, with its emphasis on private sector initiatives, redefinition and reduction of the role of the state, and promotion of new decentralized, stakeholder-driven and community-based management institutions. The new irrigation reform, relying on IMT thinking, embodies many of these characteristics. It calls for the creation of new forms of social organization WUAs - and formalization of rights and responsibilities, together with physical renovation of the irrigation schemes. The operating assumption to date is that these institutions and practices can be put in place without reference to history or the local context. This chapter has questioned that assumption by examining the dynamic arrangements that develop when new institutions and social relationships are adapted to local conditions and power relations on two smallholder irrigation schemes. The study raises two central questions that merit follow-up as the pace of irrigation reform accelerates.

Are the new directions likely to broaden smallholder irrigation scheme farmers' - especially disadvantaged ones' - access to the critical livelihood resources of land and water? Our findings indicate that many critical questions remain to be addressed concerning equity, poverty alleviation and strategies for pro-poor economic growth in the transfer of the smallholder irrigation schemes from the government to WUAs. At this point, it appears that the Domasi WUA Executive Committee and the new Likangala SMC have adopted different positions on equity and poverty-alleviation issues - with the Domasi Executive Committee focusing on productivity achieved through permitting greater concentration of plots and other resources and the Likangala SMC opting for more equitable distribution of them.

The constitutions of the two schemes draw on experiences from the past to reflect different visions of the future of smallholder irrigation in Malawi. The Likangala constitution seeks to reinstate the older top-down, state-sponsored rules ostensibly favouring more equal distribution of resources. It does this by limiting plot concentration, promoting dry-season plot rotation and restricting informal inheritance practices. The Domasi constitution, in contrast, seeks to strengthen tenure security and to promote the entrepreneurial spirit by formalizing informal practices dating from the late 1980s and early 1990s, including renting and increased land concentration. It remains to be seen whether these provisions will be put into practice and what their equity effects might be.

Second, one of the key driving assumptions underpinning these reforms is that people's rights to resources will be made more secure, thus spurring economic growth. Is this occurring on these two irrigation schemes? At this point, the study reveals lack of knowledge and understanding among officials and farmers alike about the irrigation, land and water reforms. Most farmers interviewed had no clear understanding of what their rights to land or water resources would be once transfer of the irrigation schemes was accomplished. No common understanding existed concerning key issues of membership requirements in the WUA: (i) tenure status of the scheme; (ii) whether plots could be bought, sold, rented, borrowed or inherited; and (iii) whether there would be a limit on the number of plots owned. Presently, rather than being more secure, farmers' rights to land and water resources 
appear more uncertain than they have been in the past.

\section{Acknowledgements}

This research was supported by a grant from the USAID-funded BASIS CRSP project on Institutional Dimensions of Water Policy Reform in Malawi: Addressing Critical LandWater Intersections in Broadening Access to Key Factors of Production. We would also like to acknowledge the work carried out by the BASIS field assistants over the course of the research project: Messrs Davidson Chimwaza, Mapopa Nyirongo, Noel Mbuluma and Chancy Mulima. Messrs Chimwaza and Mbuluma lived and worked on the irrigation schemes, participating in many scheme meetings and in the daily lives of the farmers for 3 years. Two BASIS-supported graduate students, Messrs Bryson Nkhoma and Daimon Kambewa, also contributed substantially to the research project.

\section{References}

Adams, W., Watson, E. and Mutiso, S. (1997) Water, rules and gender: water rights in an indigenous irrigation system, Marakwet, Kenya. Development and Change 28, 707-730.

Benjaminsen, T. and Lund, C. (2002) Formalization and informalization of land and water rights in Africa: an introduction. European Journal of Development Studies 14 (2), 1-10.

Bolding, A., Manzungu, E. and Zawe, C. (2004) Irrigation policy discourse and practice: two cases of irrigation management and transfer in Zimbabwe. In: Mollinga, P. and Bolding, A. (eds) The Politics of Irrigation Reform. Ashgate Publishing Co., Burlington, Vermont, pp. 166-206.

Cammack, D. and Chirwa, W. (1997) Development and human rights in Malawi. In: Chilowa, W. (ed.) Bwalo: Forum for Social Development, Issue 1. CSR, Zomba, Malawi, pp. 105-121.

Chilivumbo, A. (1978) On rural development: a note on Malawi's programmes for exploitation. African Development 3 (2), 41-55.

Chirwa, W. (2002) Land use and extension services at Wovwe rice scheme, Malawi. Development Southern Africa 19 (2), 307-327.

Cleaver, F. (2002) Reinventing institutions: bricolage and the social embeddedness of natural resources management. European Journal of Development Studies 14 (2), 11-30.

Derman, B., Ferguson, A. and Gonese, F. (2000) Decentralization, Devolution and Development: Reflections on the Water Reform Process in Zimbabwe. Report. BASIS CRSP, Madison, Wisconsin.

Devereux, S. (2002a) Safety nets in Malawi: the process of choice. Paper prepared for the Institute of Development Studies Conference 'Surviving the Present, Securing the Future: Social Policies for the Poor in Poor Countries', Sussex, UK.

Devereux, S. (2002b) The Malawi famine of 2002. Institute of Development Studies Bulletin, The New Famines 33 (October), 70-78.

Ferguson, A. (2005) Water reform, gender and HIV/AIDS: perspectives from Malawi. In: Whiteford, L. and Whiteford, S. (eds) Globalization, Water and Health: Resource Management in Times of Scarcity. School of American Research, Santa Fe, New Mexico, pp. 45-66.

Ferguson, A. and Mulwafu, W.O. (2001) Decentralization, participation and access to water reform in Malawi. Report prepared for the BASIS CRSP Policy Synthesis Workshop, July 2001, Johannesburg, South Africa.

Ferguson, A. and Mulwafu, W.O. (2004) Irrigation Reform on Malawi's Domasi and Likangala Smallholder Irrigation Schemes: Exploring Land-Water Intersections. Final Research Report, BASIS CRSP, Madison, Wisconsin (October).

GOM (Government of Malawi) (1965) Land Act. Government printers, Zomba, Malawi.

GOM (1968) Irrigation Ordinance. Government printers, Zomba, Malawi.

GOM (1998a) Decentralization Policy. Decentralization Secretariat, Lilongwe, Malawi.

GOM (1998b) Local Government Act. Government Printers, Zomba, Malawi.

GOM (1999a) Water Resources Policy and Strategies. Ministry of Water Development, Lilongwe, Malawi.

GOM (1999b) Draft Water Act. Ministry of Water Development, Lilongwe, Malawi.

GOM (2000) National Irrigation Policy and Development Strategy. Ministry of Agriculture and Irrigation, Lilongwe, Malawi. 
GOM (2001) Land Policy of Malawi. Ministry of Lands, Housing, Physical Planning, and Surveys, Lilongwe, Malawi.

GOM (2004) National Water Policy. Ministry of Water Development, Lilongwe, Malawi.

Juma, I. and Maganga, F. (2005) Current reforms and their implications for rural water management in Tanzania. Presented at the international workshop on African Water Laws: Plural Legislative Frameworks for Rural Water Management in Africa, 26-28 January, Johannesburg, South Africa.

Kambewa, D. (2004) Patterns of Access to and Use of Wetlands: Lake Chilwa Basin, Malawi. Report, BASIS CRSP, Madison, Wisconsin.

Kishindo, P. (1996) Farmer turn over on settlement schemes: the experience of Limphasa irrigated rice scheme, northern Malawi. Nordic Journal of African Studies 5 (1), 1-10.

Krogh, E. and Mkandawire, R.M. (1990) Life as a Rice Farmer in Malawi. Socio-Economic Survey. Smallholder Irrigation Rehabilitation Project, Bunda College of Agriculture, University of Malawi, Lilongwe, Malawi.

Mollinga, P. and Bolding, A. (eds) (2004) The Politics of Irrigation Reform. Ashgate Publishing Company, Burlington, Vermont.

Nicol, A. and Mtisi, S. (2003) Politics and water policy: a southern Africa example. IDS Bulletin 34 (3), 41-53.

Nkhoma, B.G. and Mulwafu, W.O. (2004) The experience of irrigation management transfer in two irrigation schemes in Malawi, 1960s-2002. Journal of Physics and Chemistry of the Earth, Parts A/B/C 29 (15-18), 1327-1333.

Owusu, K. and Ng'ambi, F. (2002) Structural Damage: the Causes and Consequences of Malawi's Food Crisis. World Development Movement, London.

Peters, P. (2004) Informal Irrigation in Lake Chilwa Basin: Streambank and Wetland Gardens. Report, BASIS CRSP, Madison, Wisconsin.

Shah, M., Osborne, N., Mbilizi, T. and Vilili, G. (2002) Impact of HIV/AIDS on Agricultural Productivity and Rural Livelihoods in the Central Region of Malawi. CARE International, Lilongwe, Malawi.

van Koppen, B., Sokile, C.S., Hatibu, N., Lankford, B., Mahoo, H. and Yanda, P. (2004) Formal Water Rights in Rural Tanzania: Deepening the Dichotomy? Working Paper 71, International Water Management Institute, Johannesburg, South Africa.

Vermillion, D. (1997) Impacts of Irrigation Management Transfer: a Review of the Evidence. Research Report 11, International Irrigation Management Institute, Colombo, Sri Lanka.

Vermillion, D. and Sagardoy, J.A. (1999) Transfer of Irrigation Management Services - Guidelines. FAO, Rome.

World Bank (2004) Irrigation, rural livelihoods and agricultural development project preparation/preappraisal mission, 12-24 July. Aide Memoire, World Bank, Washington, DC. 